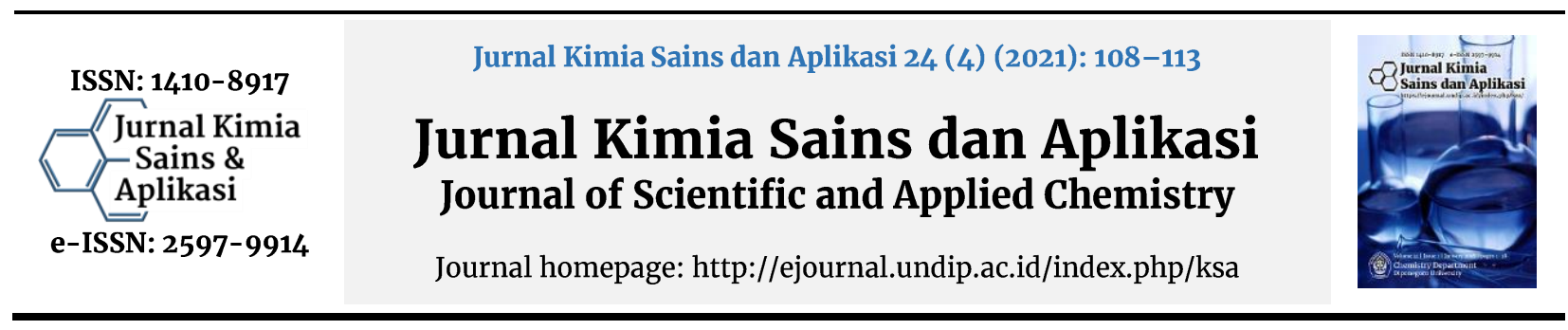

\title{
Stigmasterol and Stigmasterone from Methanol Extract of Calophyllum soulattri Burm. F. Stem Bark
}

\author{
Soerya Dewi Marliyana ${ }^{\text {a, }}$, Fajar Rakhman Wibowo ${ }^{a}$, Desi Suci Handayani ${ }^{a}$, \\ Triana Kusumaningsih $^{a}$, Venty Suryanti ${ }^{a}$, Maulidan Firdaus ${ }^{a}$, Ema Nur Annisa ${ }^{a}$ \\ ${ }^{a}$ Department of Chemistry, Universitas Sebelas Maret, Surakarta, Indonesia \\ * corresponding author: msoerya@staff.uns.ac.id \\ https://doi.org/10.14710/jksa.24.4.108-113
}

\section{Article Info}

Article history:

Received: $11^{\text {th }}$ November 2020

Revised: $30^{\text {th }}$ March 2021

Accepted: $30^{\text {th }}$ March 2021

Online: $30^{\text {th }}$ April 2021

Keywords:

Calophyllum soulattri Burm. F.; stem bark extract; steroid

\begin{abstract}
Stigmasterol and Stigmasterone from Methanol Extract of Calophyllum soulattri Burm. F. Stem Bark. Calophyllum soulattri Burm. F. has been widely used for herbal medicine. Phytochemical investigation of $C$. soulattri contains a secondary metabolite of the steroid class. Steroid compounds have various biological activities, such as anti-inflammatory, antioxidant, antiproliferative, antibacterial, antimalarial, and anticancer. Two secondary metabolites steroids have been isolated and identified from the stem bark extract of $C$. soulattri. Isolation was carried out through the extraction (maceration), fractionation, and purification stages. Maceration is carried out using methanol as a solvent. Fractionation was carried out by vacuum liquid chromatography (VLC), and purification was by flash column chromatography. Identification of combined fractions and determination of pure isolates were used through thin-layer chromatography (TLC). The solvent used in the chromatography methods was a mixture of $n$-hexane and ethyl acetate. The structure isolates were identified by FTIR, ${ }^{1} \mathrm{H}$ NMR, and ${ }^{13} \mathrm{C}$ NMR and compared with literature data. Secondary metabolites steroids that have been isolated are identical compounds to stigmasterol and stigmasterone.
\end{abstract}

\section{Introduction}

The Calophyllum genus is a type of plant that is often found in the tropical forests of Indonesia. The community has used this plant as herbal medicine, including a diuretic, blood pressure, rheumatism, malaria, sexually transmitted diseases, varicose veins, hemorrhoids, infections of the skin, nephritis, and antiinflammatory drugs [1]. One species of the genus Calophyllum is Calophyllum soulattri, known as slatri.

Secondary metabolites in $C$. soulattri that have been reported include the terpenoid group, i.e., fridelin [2], soulamarin, a derivate of coumarin [3], the steroid class, such as stigmasterol and $\beta$-sitosterol $[2,4]$. Also, there are also xanthones groups, such as soulatrin, caloxanthone-B, caloxanthone $\mathrm{C}$, macluraxanthone, phylattrin, brasixanthon, and trapezifolixanthone [5]. Some of these compounds can be found in the stems, leaves, and roots of the $C$. soulattri plant. Whereas the bark of $C$. soulattri contains xanthone groups, including
caloxanthone-B, caloxanthone-C, phylattrin, soulatrin, macluraxanthone, and brasixanthone [3], and the steroid group, such as stigmasterol [2].

Exploration of compounds in the stem bark of $C$. soulattri has not been widely carried out, especially the isolation of secondary metabolites of the steroid group. The steroid group has anti-inflammatory, antidiabetic [6], antioxidant, anti-tumor, anti-osteoarthritis, antimutagenic [7], and antibacterial activities [8]. Therefore, it is necessary to explore $C$. soulattri, especially in the stem bark section, contributing to adding a database of steroid group compounds. Furthermore, the database can be used as a source for potential medicinal compounds.

\section{Materials and Methods}

FTIR spectrophotometer Shimadzu (Kyoto, Jepang), NMR $500 \mathrm{MHz}$ Agilent (Santa Clara, USA), vacuum liquid chromatography (VLC), flash column chromatography, 
and $\mathrm{UV}_{254}$ lamp were the instruments and tools employed in this research. Methanol, $n$-hexane, ethyl acetate, and acetone were technical grades. Silica gel $60 \mathrm{G}$ (Merck; Darmstadt, Jerman), Silica gel 60 (0,04-0,063 mm) 230400 mesh ASTM (Merck; Darmstadt, Jerman), Silica gel $60(0,2-0,5 \mathrm{~mm})$ (Merck; Darmstadt, Jerman) and TLC plate (alumunium coated silica gel $60 \mathrm{~F}_{254} 0,25 \mathrm{~mm}$ (Merck; Darmstadt, Jerman)) were the adsorbent for chromatography. Cerium(IV) (Merck; Darmstadt, Jerman) and $\mathrm{H}_{2} \mathrm{SO}_{4}$ (Mallinckrodt) were used as spotting reagents.

The $C$. soulattri stem bark powder $(2.5 \mathrm{~kg})$ was macerated using methanol (10 L) solvent for $3 \times 24$ hours. The filtrate was evaporated to give $385 \mathrm{~g}$ of thick blackish brown extract. The $13 \mathrm{~g}$ methanol extract was fractionated using VLC with a solvent mixture of nhexane: ethyl acetate $(10: 0 ; 9: 1 ; 8: 2 ; 7: 3 ; 6: 4 ; 5: 5 ; 4$ : $6 ; 3: 7 ; 2: 8 ; 1: 9 ; 0: 10$ ) with a grading system that produced 20 fractions. The selection of fractions to be purified based on TLC analysis. TLC results were seen with a UV lamp $\left(\lambda_{254}\right)$ then sprayed with spotting reagent $\mathrm{Ce}\left(\mathrm{SO}_{4}\right)_{2}$. The fractions having the same TLC profile were combined and purified by flash column chromatography.

Based on the TLC profile, fractions 1-9 were further purified using a mixture of eluent $n$-hexane: ethyl acetate with a ratio of 9.5: $0.5(200 \mathrm{~mL})$; while each ratio of 9:1, 8:2, 7:3, 6:4, and 5:5 in a volume of $100 \mathrm{~mL}$, and $150 \mathrm{~mL}$ of $100 \%$ acetone, which gives 72 fractions. The fractions F19-21 and F28 were chosen to be tested for purity because they showed one spot. The fraction F1921 hereinafter referred to as F19, and F28 were identified for their structure using FTIR, ${ }^{1} \mathrm{H}$ NMR, and ${ }^{13} \mathrm{C} N M R$ spectroscopy methods.

\section{Results and Discussion}

\subsection{Identification of $\mathrm{F} 19$ Compound}

The isolation of the stem bark extract of $C$. soulattri resulted in two pure isolates, namely F19 and F28. Analysis of the IR spectrum of F19 shows the presence of hydroxy group ( $-\mathrm{OH})$ absorption at around 3400-3500 $\mathrm{cm}^{-1}$ (broad). The IR spectrum also shows the presence of aliphatic $\mathrm{C}-\mathrm{H}$ stretching vibrations at around 2900$2800 \mathrm{~cm}^{-1}$ (sharp) and weak absorption of alkenes (C=C) around $1600 \mathrm{~cm}^{-1}$ (sharp). The absorption at $1400 \mathrm{~cm}^{-1}$ (sharp) is the absorption of $\mathrm{CH}_{2}$ bending, while the absorption at around $1000-1100 \mathrm{~cm}^{-1}$ (sharp) is the absorption of cycloalkanes. Based on FTIR results, and compared with literature data, isolate F19 is a steroid compound [9]. The FTIR absorption data are shown in Figure 1 and Table 1. Further analysis of the ${ }^{1} \mathrm{H}$ NMR and ${ }^{13} \mathrm{C}$ NMR data was carried out.

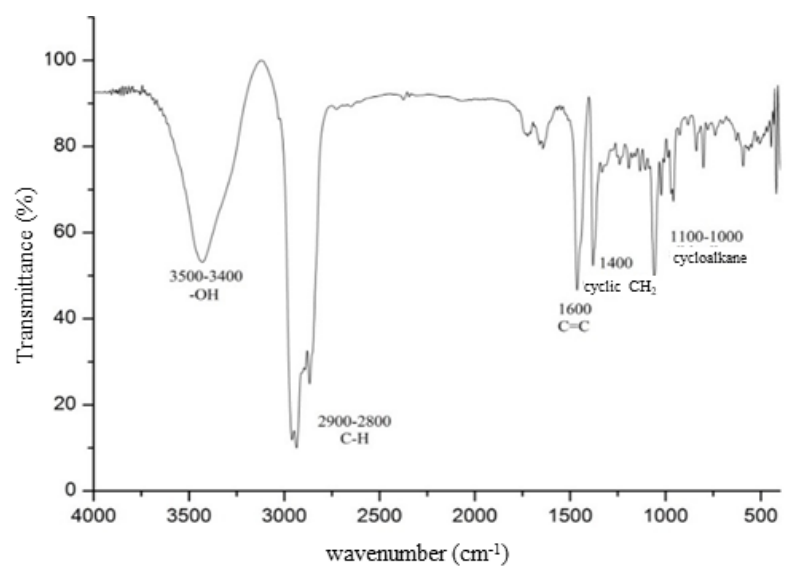

Figure 1. FTIR spectrum of F19 compound

Table 1. FTIR data comparison of F19 compound with literature(F19*)

\begin{tabular}{ccc}
\hline $\mathrm{F} 19\left(\mathrm{~cm}^{-1}\right)$ & $\mathrm{F} 19^{*}\left(\mathrm{~cm}^{-1}\right)$ & Vibrations \\
\hline 3427 & 3547 & -OH stretching, broad \\
2891 & 2857 & C-H bending, sharp \\
1643 & 1638 & C=C weak, sharp \\
1463 & 1462 & CH2 bending, sharp \\
1058 & 1071 & cycloalkanes, sharp \\
\hline
\end{tabular}

$\mathrm{F}_{19}$ : measured in $\mathrm{KBr}$

$\mathrm{F}_{19} *$ : reference compound measured in $\mathrm{KBr}$ [9]

Identification of F19 with NMR, including ${ }^{13} \mathrm{C}$ NMR and ${ }^{1} \mathrm{H}$ NMR, was carried out in $\mathrm{CDCl}_{3}$ solvent. The ${ }^{1} \mathrm{H}$ NMR spectrum analysis data (Figure 2) shows the presence of 48 proton signals. The proton signal in the chemical shift $\left(\delta_{\mathrm{H}}\right)$ from 0.67 to $2.3 \mathrm{ppm}$ is a signal from the proton $s p^{3}$ consisting of methine $(\mathrm{CH})$, methylene $\left(\mathrm{CH}_{2}\right)$, and methyl $\left(\mathrm{CH}_{3}\right)$. The presence of 6 methyl groups is indicated by the proton signals at $\delta_{\mathrm{H}}(\mathrm{ppm})$ 0.69 (3H, s, H-18); 1.01 (3H, s, H-19); 1.02 (3H, m, H-21); $0.85(3 \mathrm{H}, \mathrm{m}, \mathrm{H}-26) ; 0.80(3 \mathrm{H}, \mathrm{m}, \mathrm{H}-27)$ and $0.81(3 \mathrm{H}, \mathrm{m}$, $\mathrm{H}-29)$. The 9 methylene $\left(\mathrm{CH}_{2}\right)$ groups are indicated by the presence of proton signal at $\delta_{\mathrm{H}}(\mathrm{ppm}) 1.84(2 \mathrm{H}, \mathrm{m}$, $\mathrm{H}-1)$; 1.83 (2H, m, H-2); 2,3 (2H, m, H-4); 1.97 (2H, m, $\mathrm{H}-7) ; 1.50$ (2H, m, H-11); $2.00(2 \mathrm{H}, \mathrm{m}, \mathrm{H}-12) ; 1.56(2 \mathrm{H}$, $\mathrm{m}, \mathrm{H}-15) ; 1.72(2 \mathrm{H}, \mathrm{m}, \mathrm{H}-16)$ and $1.44(2 \mathrm{H}, \mathrm{m}, \mathrm{H}-28)$. In addition, there are also 11 methine groups indicated by the presence of a proton signal at $\delta_{\mathrm{H}}(\mathrm{ppm}) 3.52(1 \mathrm{H}, \mathrm{m}$, $\mathrm{H}-3) ; 1.46(1 \mathrm{H}, \mathrm{m}, \mathrm{H}-8) ; 0.92(1 \mathrm{H}, \mathrm{m}, \mathrm{H}-9) ; 1.01(1 \mathrm{H}, \mathrm{m}$, $\mathrm{H}-14) ; 1.15$ (1H, m, H-17); $2.06(1 \mathrm{H}, \mathrm{m}, \mathrm{H}-20) ; 1.54(1 \mathrm{H}$, $\mathrm{m}, \mathrm{H}-24)$ and $1.55(1 \mathrm{H}, \mathrm{m}, \mathrm{H}-25)$. There is an alkene proton signal at a chemical shift of $5.35(1 \mathrm{H}, \mathrm{m}, \mathrm{H}-6)$; $5.04(1 \mathrm{H}, \mathrm{ss}, \mathrm{J}=8.65 ; 15.2 \mathrm{~Hz}, \mathrm{H}-22)$; 5.1 ( $1 \mathrm{H}, \mathrm{dd}, \mathrm{J}=8.65$; $15.15 \mathrm{~Hz}, \mathrm{H}-23)$ which is the main feature of the steroid framework. This ${ }^{1} \mathrm{H}$ NMR data analysis is supported by ${ }^{13} \mathrm{C}$ NMR data. 


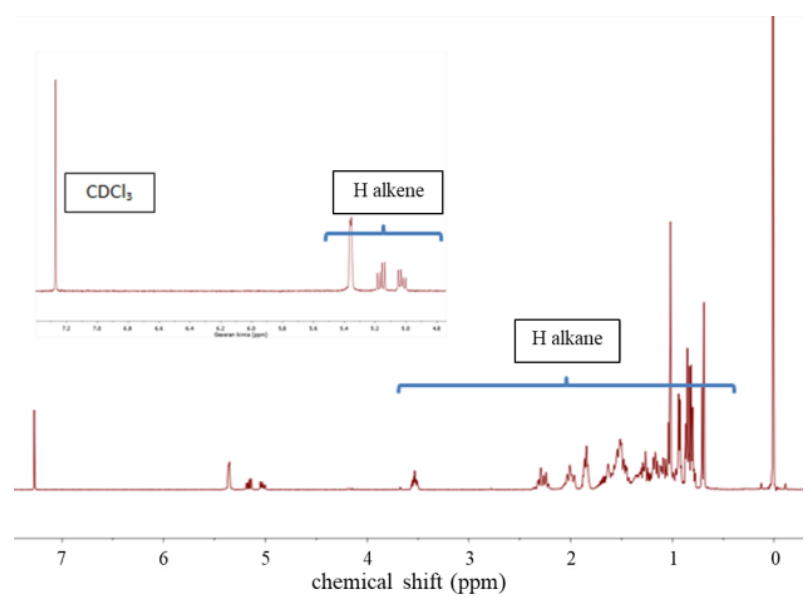

Figure 2. ${ }^{1} \mathrm{H}$ NMR spectrum of F19 compound

The ${ }^{13} \mathrm{C}$ NMR spectrum (Figure 3) shows the presence of 29 carbon atom signals, each signal having a distinctive shift. The chemical shift of carbon $\left(\delta_{\mathrm{C}}\right)$ 12.0$71.9 \mathrm{ppm}$ shows a signal from $\mathrm{C} \mathrm{s} p^{3}$ which consists of six methyl groups $\left(\mathrm{CH}_{3}\right)$ at $\delta_{\mathrm{C}} 12.0(\mathrm{C}-18) ; 19.1(\mathrm{C}-19) ; 23.2$ (C-21); 21.2 (C-26); 21.3 (C-27); 12.1 (C-29) ppm. In addition, nine methylene $\left(\mathrm{CH}_{2}\right)$ groups at $\delta \mathrm{c} 36.6(\mathrm{C}-1)$; 29.3 (C-2); 42.3 (C-4); 31.8 (C-7); 24.4 (C-11); 39.8 (C12); $24.5(\mathrm{C}-15) ; 28.4(\mathrm{C}-16) ; 25.5(\mathrm{C}-28) \mathrm{ppm}$ was also identified. The presence of 11 metine $(\mathrm{CH})$ groups is shown at $\delta_{\mathrm{C}} 71.9(\mathrm{C}-3) ; 29.0(\mathrm{C}-8) ; 50.2(\mathrm{C}-9) ; 56.9$ (C14); 56.1 (C-17); 39.9 (C-20); $51.3(\mathrm{C}-24) ; 34.1(\mathrm{C}-25)$ and $3 \mathrm{C}$ quaternary $(\mathrm{Cq})$ at $\delta_{\mathrm{C}} 140.9(\mathrm{C}-5) ; 36.3(\mathrm{C}-10) ; 40.6$ (C-13) ppm. The alkene $\mathrm{C}$ signal is found at $121.8(\mathrm{C}-6)$; 138.4 (C-22); and 129.4 (C-23). The obtained NMR data were then compared with literature data $[9,10]$ (Table 2).

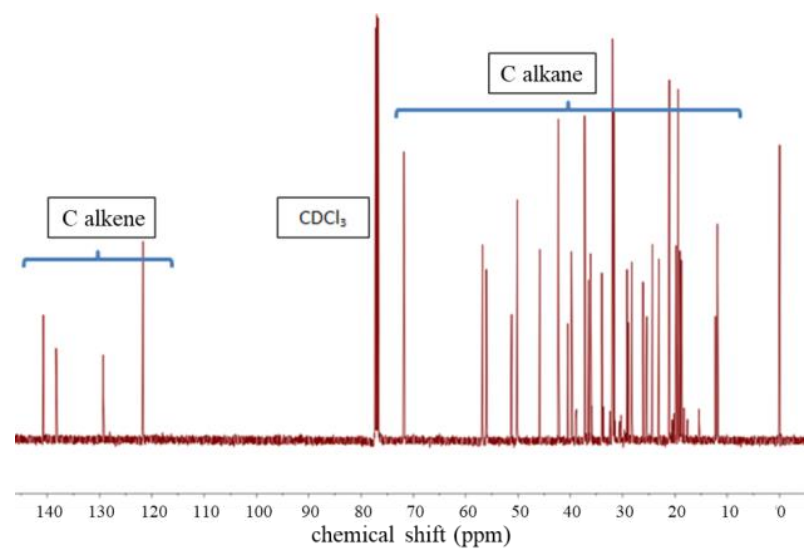

Figure3. ${ }^{13} \mathrm{C}$ NMR spectrum of F19 compound

Based on the analysis of FTIR, ${ }^{1} \mathrm{H}$ NMR, and ${ }^{13} \mathrm{C}$ NMR data, as well as the results of comparisons with literature data, compound $\mathrm{F} 19$ is a compound identical to stigmasterol ( $\mathrm{F} 19^{*}$ ) with the molecular formula $\mathrm{C}_{29} \mathrm{H}_{48} \mathrm{O}$, as shown in Figure 4. Stigmasterol which has been isolated from the stem bark of $C$. soulattri, is also found in many other plants, such as Neocarya macrophylla [11], Ficus hispida [12], and Terminalia schimperiana [13].
Table 2. NMR data comparison of F19 compound with literature $\left(\mathrm{F} 19^{*}\right)$

\begin{tabular}{|c|c|c|c|c|}
\hline \multirow{2}{*}{$\begin{array}{c}\text { No. } \\
\text { C }\end{array}$} & \multicolumn{2}{|c|}{$\delta_{\mathrm{H}}($ multiplicity, Jin $\mathrm{Hz})$} & \multicolumn{2}{|c|}{$\delta_{\mathrm{C}}(\mathrm{ppm})$} \\
\hline & F19 & F19* & F19 & F19* \\
\hline 1 & $1.84(\mathrm{~m})$ & $1.84(\mathrm{~m})$ & 36.6 & 36.7 \\
\hline 2 & $1.83(\mathrm{~m})$ & $1.83(\mathrm{~m})$ & 29.3 & 29.7 \\
\hline 3 & $3.52(\mathrm{~m})$ & $3.51(\mathrm{~m})$ & 71.9 & 71.9 \\
\hline 4 & $2.3(\mathrm{~m})$ & $2.3(\mathrm{~m})$ & 42.3 & 42.3 \\
\hline 5 & - & - & 140.9 & 140.9 \\
\hline 6 & $5.35(\mathrm{~m})$ & $5.34(\mathrm{~m})$ & 121.8 & 121.3 \\
\hline 7 & $1.97(\mathrm{~m})$ & $1.97(\mathrm{~m})$ & 31.8 & 31.7 \\
\hline 8 & $1.46(\mathrm{~m})$ & $1.46(\mathrm{~m})$ & 29.0 & 29.2 \\
\hline 9 & $0.92(\mathrm{~m})$ & $0.94(\mathrm{~m})$ & 50.2 & 50.0 \\
\hline 10 & - & - & 36.3 & 36.1 \\
\hline 11 & $1.50(\mathrm{~m})$ & $1.50(\mathrm{~m})$ & 24.4 & 24.3 \\
\hline 12 & $2.00(\mathrm{~m})$ & $2.00(\mathrm{~m})$ & 39.8 & 39.8 \\
\hline 13 & - & - & 40.6 & 40.4 \\
\hline 14 & $1.01(\mathrm{~m})$ & $1.01(\mathrm{~m})$ & 56.9 & 56.9 \\
\hline 15 & $1.56(\mathrm{~m})$ & $1.56(\mathrm{~m})$ & 24.5 & 24.3 \\
\hline 16 & $1.72(\mathrm{~m})$ & $1.72(\mathrm{~m})$ & 28.4 & 28.9 \\
\hline 17 & $1.15(\mathrm{~m})$ & $1.15(\mathrm{q})$ & 56.1 & 56.0 \\
\hline 18 & $0.69(\mathrm{~s})$ & $0.70(\mathrm{~s})$ & 12.0 & 12.0 \\
\hline 19 & $1.01(\mathrm{~s})$ & $1.01(\mathrm{~s})$ & 19.1 & 19.0 \\
\hline 20 & $2.06(\mathrm{~m})$ & $2.06(\mathrm{~m})$ & 39.9 & 39.8 \\
\hline 21 & $1.02(\mathrm{~m})$ & $1.03(\mathrm{~m})$ & 23.2 & 23.1 \\
\hline 22 & $\begin{array}{c}5.17(\mathrm{dd}, 15.2 \\
8.65)\end{array}$ & $\begin{array}{c}5.16(\mathrm{dd}, 15.08 \\
8.62)\end{array}$ & 138.4 & 138.4 \\
\hline 23 & $\begin{array}{c}5.03(\mathrm{dd}, 15.15 \\
8.65)\end{array}$ & $\begin{array}{c}5.03(\mathrm{dd}, 15.03 \\
8.62)\end{array}$ & 129.4 & 129.3 \\
\hline 24 & $1.54(\mathrm{~m})$ & $1.54(\mathrm{~m})$ & 51.3 & 51.2 \\
\hline 25 & $1.55(\mathrm{~m})$ & $1.55(\mathrm{~m})$ & 34.1 & 34.1 \\
\hline 26 & $0.85(\mathrm{~m})$ & $0.85(\mathrm{~d})$ & 21.2 & 21.1 \\
\hline 27 & $0.80(\mathrm{~m})$ & $0.80(\mathrm{~d})$ & 21.3 & 22.8 \\
\hline 28 & $1.44(\mathrm{~m})$ & $1.43(\mathrm{~m})$ & 25.5 & 25.3 \\
\hline 29 & $0.81(\mathrm{~m})$ & $0.81(t)$ & 12.1 & 12.0 \\
\hline
\end{tabular}

$\mathrm{F}_{19}$ : measured in $\mathrm{CDCl}_{3}, 500 \mathrm{MHz}\left({ }^{1} \mathrm{H}\right)$ and $125 \mathrm{MHz}\left({ }^{13} \mathrm{C}\right)$ $\mathrm{F}_{19} *$ : measured in $\mathrm{CDCl}_{3}, 400 \mathrm{MHz}\left({ }^{1} \mathrm{H}\right)$ dan $100 \mathrm{MHz}\left({ }^{13} \mathrm{C}\right)$ $[9,10]$

Based on the analysis of FTIR, ${ }^{1} \mathrm{H}$ NMR, and ${ }^{13} \mathrm{C}$ NMR data, as well as the results of comparisons with literature data, compound $\mathrm{F} 19$ is a compound identical to stigmasterol ( $\mathrm{F} 19^{*}$ ) with the molecular formula $\mathrm{C}_{29} \mathrm{H}_{48} \mathrm{O}$, as shown in Figure 4. Stigmasterol which has been isolated from the stem bark of $C$. soulattri, is also found in many other plants, such as Neocarya macrophylla [11], Ficus hispida [12], and Terminalia schimperiana [13].<smiles>CC[C@H](/C=C/[C@@H](C)[C@H]1CCC2C3CC=C4CC(O)CC[C@]4(C)C3CC[C@@]21C)C(C)C</smiles>

Figure 4. Stigmasterol structure. 


\subsection{Identification of $\mathbf{F} 28$ compound}

Analysis of the F28 compound IR spectrum shows the absorption at around $3400-3500 \mathrm{~cm}^{-1}$ (broad), which is characteristic of the hydroxy $(-\mathrm{OH})$ group. The presence of aliphatic $\mathrm{C}-\mathrm{H}$ stretching vibration and alkene $(C=C)$ vibration was shown at around 2900-2800 $\mathrm{cm}^{-1}$ (sharp) and around $1600 \mathrm{~cm}^{-1}$ (sharp). The presence of a carbonyl group $(\mathrm{C}=\mathrm{O})$ is indicated by absorption at around $1700 \mathrm{~cm}^{-1}$ (sharp). The absorption at $1400 \mathrm{~cm}^{-1}$ (sharp) is the $\mathrm{CH}_{2}$ bending vibration. Besides, there is cycloalkane absorption at around 1000-1100 cm (sharp). The IR spectrum of F28 compared with the literature $[9,14]$ are shown in Figure 5 and Table 3. Further analysis of the ${ }^{1} \mathrm{H}$ NMR and ${ }^{13} \mathrm{C}$ NMR data was carried out.

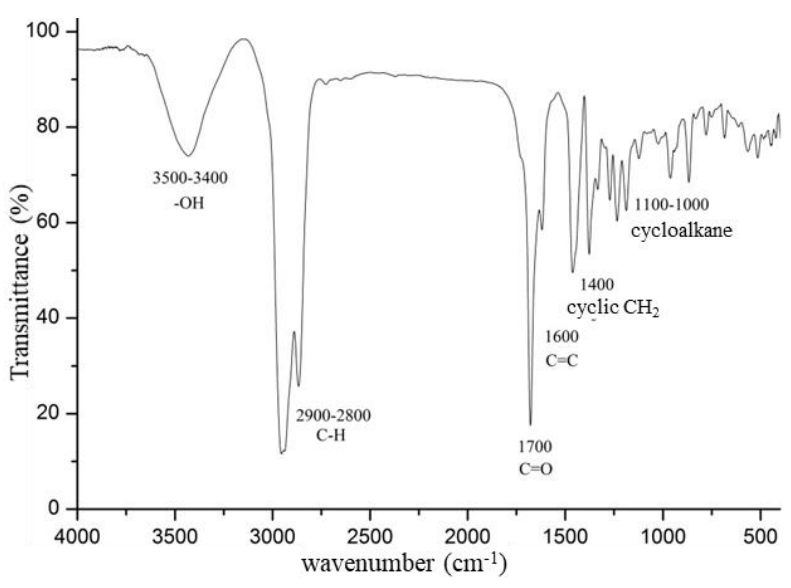

Figure 5. The FTIR spectrum of the F28 compound

Table 3. FTIR data comparison of F28 and Literature (F28*)

\begin{tabular}{ccc}
\hline F28 $\left(\mathrm{cm}^{-1}\right)$ & F28* $\left(\mathrm{cm}^{-1}\right)$ & Vibrations \\
\hline 3430 & 3547 & -OH stretching, broad \\
2867 & 2857 & C-H sharp \\
1678 & 1715 & C=O sharp \\
1619 & 1638 & C=C weak \\
1462 & 1462 & $\mathrm{CH}_{2}$ bending, sharp \\
1122 & 1071 & cycloalkane, sharp \\
\hline
\end{tabular}

Compound $\mathrm{F}_{28}$ : measured in $\mathrm{KBr}$

Compound $\mathrm{F}_{28} *$ : measured in $\mathrm{KBr}[9,11]$

Identification of $\mathrm{F} 28$ was carried out in $\mathrm{CDCl}_{3}$ solvent using NMR spectroscopy, including ${ }^{13} \mathrm{C}$ NMR and $1 \mathrm{H}$ NMR. The $1 \mathrm{H}$ NMR spectrum (Figure 6) reveals the presence of 52 proton signals. The proton signal in chemical shift $\left(\delta_{\mathrm{H}}\right)$ from 0.70 to $2.38 \mathrm{ppm}$ is a signal from the proton $s p^{3}$ consisting of methyl $\left(\mathrm{CH}_{3}\right)$, methylene $\left(\mathrm{CH}_{2}\right)$, and methine $(\mathrm{CH})$. The proton signal for 6 methyl groups is shown at $\delta_{\mathrm{H}}(\mathrm{ppm}) 0.71(3 \mathrm{H}, \mathrm{s}, \mathrm{H}-18) ; 1.01(3 \mathrm{H}$, $\mathrm{s}, \mathrm{H}-19) ; 1.03$ (3H, m, H-21); 0.85 (3H, m, H-26); 0.80 $(3 \mathrm{H}, \mathrm{m}, \mathrm{H}-27)$ and $0.82(3 \mathrm{H}, \mathrm{m}, \mathrm{H}-29)$. The presence of a methylene group $\left(\mathrm{CH}_{2}\right)$ is indicated by a proton signal with $\delta_{\mathrm{H}}(\mathrm{ppm}) 1.50(2 \mathrm{H}, \mathrm{m}, \mathrm{H}-11) ; 2.00(2 \mathrm{H}, \mathrm{m}, \mathrm{H}-12)$; $1.57(2 \mathrm{H}, \mathrm{m}, \mathrm{H}-15) ; 1.72(2 \mathrm{H}, \mathrm{m}, \mathrm{H}-16)$ and $1.43(2 \mathrm{H}, \mathrm{m}$, $\mathrm{H}-28)$. While the methine group is indicated by a proton signal at $\delta_{\mathrm{H}}(\mathrm{ppm}) 1.01(1 \mathrm{H}, \mathrm{m}, \mathrm{H}-14) ; 1.15(1 \mathrm{H}, \mathrm{m}, \mathrm{H}-17)$; $2.03(1 \mathrm{H}, \mathrm{m}, \mathrm{H}-20) ; 1.54(1 \mathrm{H}, \mathrm{m}, \mathrm{H}-24)$ and $1.55(1 \mathrm{H}, \mathrm{m}$,
$\mathrm{H}-25)$. There is an alkene proton signal on chemical shift $5.17(1 \mathrm{H}, \mathrm{dd}, J=8.55 ; 15.1 \mathrm{~Hz}, \mathrm{H}-22) ; 5.04(1 \mathrm{H}, \mathrm{dd}, J=8.6$; $15.1 \mathrm{~Hz}, \mathrm{H}-23)$, which is the main feature of the steroid framework. This $1 \mathrm{H}$ NMR data analysis is supported by ${ }^{13} \mathrm{C}$ NMR data.

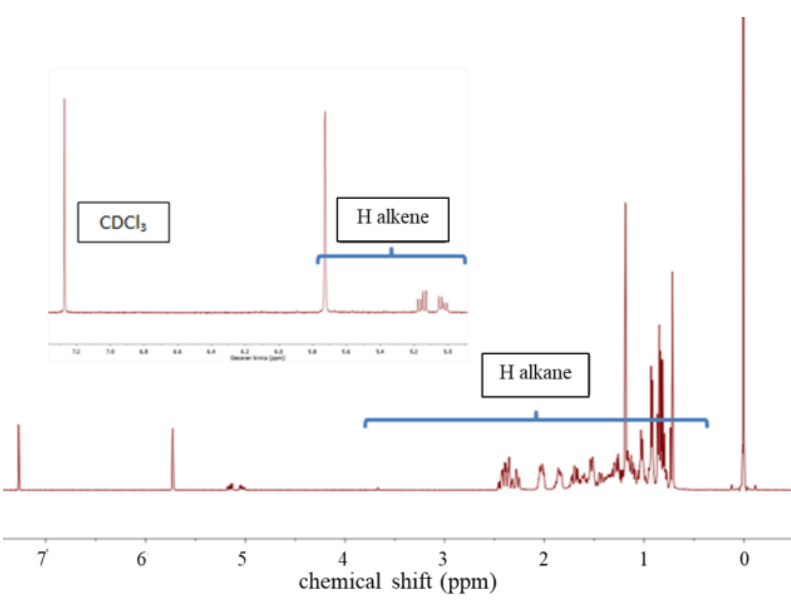

Figure 6. The ${ }^{1} \mathrm{H}$ NMR spectrum of the F28 compound

The ${ }^{13} \mathrm{C}$ NMR spectrum (Figure 7) shows a carbon signal at $\delta_{\mathrm{C}}$ 12.0-56.2 ppm which is a signal from $\mathrm{C} s p^{3}$ consisting of 6 methyl groups $\left(\mathrm{CH}_{3}\right)$ at $\delta_{\mathrm{C}} 12.0(\mathrm{C}-18) ; 19.1$ (C-19); 18.8 (C-21); 21.1 (C-26); 21.2 (C-27); 12.1 (C-29) ppm. In addition, methylene $\left(\mathrm{CH}_{2}\right)$ groups are also appeared at $\delta_{\mathrm{C}} 24.4(\mathrm{C}-11) ; 39.7(\mathrm{C}-12) ; 24.3(\mathrm{C}-15) ; 28.3$ (C-16); $25.5(\mathrm{C}-28) \mathrm{ppm}$. The presence of a methine $(\mathrm{CH})$ group is indicated at $\delta_{\mathrm{C}} 56.1(\mathrm{C}-14) ; 56.0(\mathrm{C}-17) ; 42.4(\mathrm{C}-$ 20); $51.4(\mathrm{C}-24) ; 34.1(\mathrm{C}-25)$ and $\mathrm{C}$ quaternary $(\mathrm{Cq})$ at $\delta \mathrm{C}$ $42.5(\mathrm{C}-13) \mathrm{ppm}$. The alkene signal is identified at $\mathbf{1 3 8 . 2}$ (C-22); and 129.5 (C-23) ppm. The carbonyl group is denoted by the $C$ signal at $200.0 \mathrm{ppm}$, which is a signal from the ketone group, while the appearance of the signal at $178 \mathrm{ppm}$ is a signal of the carboxylate group from the impurity. Furthermore, the NMR analysis data were compared with literary data $[9,10]$, as shown in Table 4.

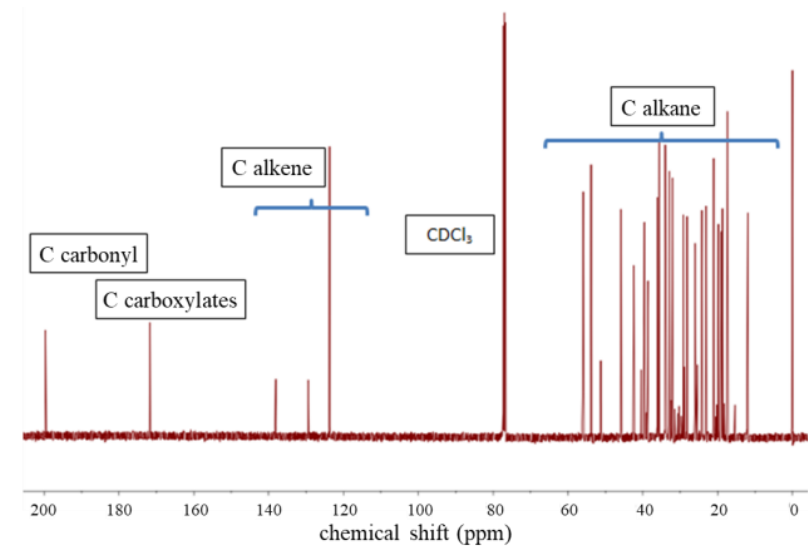

Figure 7. The ${ }^{13} \mathrm{C}$ NMR spectrum of the F28 compound 
Table 4.NMR data comparison of F28 and literature $\left(\mathrm{F} 28^{*}\right)$ compounds

\begin{tabular}{|c|c|c|c|c|}
\hline \multirow{2}{*}{ No. } & \multicolumn{2}{|c|}{$\delta_{\mathrm{H}}($ multiplicity, Jin Hz) } & \multicolumn{2}{|c|}{$\delta_{\mathrm{c}}(\mathrm{ppm})$} \\
\hline & F28 & F28* & F28 & F28* \\
\hline 11 & $1.50(\mathrm{~m})$ & $1.50(\mathrm{~m})$ & 24.4 & 24.3 \\
\hline 12 & $2.00(\mathrm{~m})$ & $2.00(\mathrm{~m})$ & 39.7 & 39.8 \\
\hline 13 & - & - & 42.5 & 40.4 \\
\hline 14 & $1.01(\mathrm{~m})$ & $1.01(\mathrm{~m})$ & 56.1 & 56.9 \\
\hline 15 & $1.57(\mathrm{~m})$ & $1.56(\mathrm{~m})$ & 24.3 & 24.3 \\
\hline 16 & $1.72(\mathrm{~m})$ & $1.72(\mathrm{~m})$ & 28.3 & 28.9 \\
\hline 17 & $1.15(\mathrm{~m})$ & $1.15(q)$ & 56.0 & 56.0 \\
\hline 18 & $0.71(s)$ & $0.70(\mathrm{~s})$ & 12.0 & 12.0 \\
\hline 19 & $1.01(\mathrm{~s})$ & $1.01(\mathrm{~s})$ & 19.1 & 19.0 \\
\hline 20 & $2.03(\mathrm{~m})$ & $2.06(\mathrm{~m})$ & 42.4 & 39.8 \\
\hline 21 & $1.03(\mathrm{~m})$ & $1.03(\mathrm{~m})$ & 18.8 & 23.1 \\
\hline 22 & $\begin{array}{c}5.17(\mathrm{dd} \\
15.1 ; 8.55)\end{array}$ & $\begin{array}{c}5.17(\mathrm{dd} \\
22.2 ; 15.2)\end{array}$ & 138.2 & 138.4 \\
\hline 23 & $\begin{array}{l}5.04(\mathrm{dd} \\
15.1 ; 8.6)\end{array}$ & $\begin{array}{l}5.04(\mathrm{dd} \\
23.2 ; 8.6)\end{array}$ & 129.5 & 129.3 \\
\hline 24 & $1.54(\mathrm{~m})$ & $1.54(\mathrm{~m})$ & 51.4 & 51.2 \\
\hline 25 & $1.55(\mathrm{~m})$ & $1.55(\mathrm{~m})$ & 34.1 & 34.1 \\
\hline 26 & $0.85(\mathrm{~m})$ & $0.85(d)$ & 21.1 & 21.1 \\
\hline 27 & $0.80(\mathrm{~m})$ & $0.80(d)$ & 21.2 & 22.8 \\
\hline 28 & $1.43(\mathrm{~m})$ & $1.43(\mathrm{~m})$ & 25.5 & 25.3 \\
\hline 29 & $0.82(\mathrm{~m})$ & $0.81(t)$ & 12.1 & 12.0 \\
\hline
\end{tabular}

$\mathrm{F}_{28}$ : measured in $\mathrm{CDCl}_{3}, 500 \mathrm{MHz}\left({ }^{1} \mathrm{H}\right)$ and $125 \mathrm{MHz}\left({ }^{13} \mathrm{C}\right)$ $\mathrm{F}_{28} *$ : measured in $\mathrm{CDCl}_{3}, 400 \mathrm{MHz}\left({ }^{1} \mathrm{H}\right)$ and $100 \mathrm{MHz}\left({ }^{13} \mathrm{C}\right)$ $[9,10]$

Based on the overall results of FTIR, ${ }^{1} \mathrm{H}$ NMR, and ${ }^{13} \mathrm{C}$ NMR data analysis, and compared with literature data, the suggested compound structure for compound F28 is similar to stigmasterone with the molecular formula $\mathrm{C}_{29} \mathrm{H}_{46} \mathrm{O}$ [15], the structure of stigmasterone is shown in Figure 2. Based on a literature review, stigmasterone was first discovered in the bark of $C$. soulattri.<smiles>CCC(/C=C/[C@H](C)[C@H]1CC[C@H]2C3CC=C4CC(=O)CC[C@]4(C)C3CC[C@@]21C)C(C)C</smiles>

Figure 8. Stigmasterone structure.

Two secondary metabolites of the steroid class that have been isolated from the bark of $C$. soulattri, namely stigmasterol and stigmasterone, contribute to increasing the database of $C$. soulattri, which can then be used as a source of medicinal compounds. Based on the literature review, stigmasterone was isolated from $C$. soulattri for the first time. Apart from C. soulattri stigmasterone, it is found in Amaranthus spinosus [16] and Virola surinamensis [17].

\section{Conclusion}

Two secondary metabolites of the steroid class have been isolated from the stem bark of $C$. soulattri, which are identical compounds to stigmasterol and stigmasterone. Based on the literature review, stigmasterone was isolated for the first time in extracting the stem bark of C. soulatri.

\section{Acknowledgment}

This research was funded by the PNBP UNS 2020 with the scheme Hibah Grup Riset with contract number: 452/UN27.21/PN/2020.

\section{References}

[1] Xiao-Hui Su, Man-Li Zhang, Li-Geng Li, ChangHong Huo, Yu-Cheng Gu, Qing-Wen Shi, Chemical Constituents of the Plants of the Genus Calophyllum, Chemistry \& Biodiversity, 5, 12, (2008), 2579-2608

https://doi.org/10.1002/cbdv.200890215

[2] Siau Hui Mah, Gwendoline Cheng Lian Ee, Mawardi Rahmani, Yun Hin Taufiq-Yap, Mohd Aspollah Sukari, Soek Sin Teh, A New Pyranoxanthone from Calophyllum soulattri, Molecules, 16, 5, (2011), 3999-4004 https://doi.org/10.3390/molecules16053999

[3] Gwendoline Cheng Lian Ee, Siau Hui Mah, Soek Sin Teh, Mawardi Rahmani, Rusea Go, Yun Hin TaufiqYap, Soulamarin, a New Coumarin from Stem Bark of Calophyllum soulattri, Molecules, 16, 11, (2011), 9721-9727 https://doi.org/10.3390/molecules16119721

[4] Siau Hui Mah, Gwendoline Cheng Lian Ee, Soek Sin Teh, Mawardi Rahmani, Yang Mooi Lim, Rusea Go, Phylattrin, a New Cytotoxic Xanthone from Calophyllum soulattri, Molecules, 17, 7, (2012), 8303-8311

https://doi.org/10.3390/molecules17078303

[5] J. C. Gómez-Verjan, K. D. Rodríguez-Hernández, R. Reyes-Chilpa, Chapter 8 - Bioactive Coumarins and Xanthones From Calophyllum Genus and Analysis of Their Druglikeness and Toxicological Properties, in: R. Atta ur (Ed.) Studies in Natural Products Chemistry, Elsevier, 2017

https://doi.org/10.1016/B978-0-444-63930-1.00008-9

[6] Muhammad Aurang Zeb, Saadat Ullah Khan, Taj Ur Rahman, Muhammad Sajid, Shah Seloni, Isolation and Biological Activity of $\beta$-Sitosterol and Stigmasterol from the Roots of Indigofera heterantha, Pharmacy \& Pharmacology International Journal, 5, 5, (2017), 204-207

https://doi.org/10.15406/ppij.2017.05.00139

[7] Navpreet Kaur, Jasmine Chaudhary, Akash Jain, Lalit Kishore, Stigmasterol: A Comprehensive Review, International Journal of Pharmaceutical Sciences and Research, 2, 9, (2011), 2259-2265 https://doi.org/10.13040/IJPSR.0975-8232.2(9).2259-65

[8] Geone Corrêa, V. G. C. Abreu, D. A. Martins, Jacqueline Takahashi, Humberto Fontoura, Denise Carmona Cara, Dorila Piló-Veloso, A. F. A. Carvalho, Anti-inflammatory and antimicrobial activities of steroids and triterpenes isolated from aerial parts of Justicia acuminatissima (Acanthaceae), International Journal of Pharmacy and Pharmaceutical Sciences, 6, 6, (2014), 75-81 
[9] Luhata Lokadi Pierre, Munkombwe Namboole Moses, Isolation and Characterisation of Stigmasterol and B -Sitosterol from Odontonema Strictum (Acanthaceae), Journal of Innovations in Pharmaceuticals and Biological Sciences, 2, 1, (2015), 88-95 https://doi.org/10.13140/RG.2.1.3689.7365

[10] Peter Forgo, Katalin E. Kövér, Gradient enhanced selective experiments in the $1 \mathrm{H}$ NMR chemical shift assignment of the skeleton and side-chain resonances of stigmasterol, a phytosterol derivative, Steroids, 69, 1, (2004), 43-50 https://doi.org/10.1016/j.steroids.2003.09.012

[11] A. J. Yusuf, M. I. Abdullahi, A. K. Haruna, A. Y. Idris, A. M. Musa, Isolation and Characterization of Stigmasterol and Bis-(5, 7-diacetyl-catechin-4'$\alpha$-rhamnopyranoside) from the Stem bark of Neocarya macrophylla (Sabine) Prance (Chrysobalanaceae), Nigerian Journal of Basic and Applied Sciences, 23, 1, (2015), 15-22 https://doi.org/10.4314/njbas.v23i1.3

[12] P. Muthukrishnan, P. Prakash, B. Jeyaprabha, K. Shankar, Stigmasterol extracted from Ficus hispida leaves as a green inhibitor for the mild steel corrosion in $1 \mathrm{M} \mathrm{HCl}$ solution, Arabian Journal of Chemistry, 12, 8, (2019), 3345-3356 https://doi.org/10.1016/j.arabjc.2015.09.005

[13] Muluh Emmanuel Khan, Lodiya Maxwell Bala, Muniratu Maliki, Phytochemical analyses of Terminalia schimperiana (Combretaceae) root bark extract to isolate stigmasterol, Advanced Journal of Chemistry-Section A, 2, 4, (2019), 327-334 https://doi.org/10.33945/SAMI/AJCA.2019.4.6

[14] Josiane Aparecida de Lima, Ivana Lícia de Campos Gavioli, Cristina Maria Pacheco Barbosa, Alexandre Berndt, Flávia Maria de Andrade Gimenes, Claudia Cristina de Paro Paz, Eduardo Antonio da Cunha, Soybean silage and sugarcane tops silage on lamb performance, Ciência Rural, 43, 8, (2013), 1478-1484 https://doi.org/10.1590/S0103-84782013005000098

[15] Emmanuel Ngeufa Happi, Simone Véronique Fannang, Marie Fomani, Suzye Mireille Moladje Donkwe, Nkoungou Yomzak Carine Nicaise, Jean Duplex Wansi, Norbert Sewald, Steroids and Ceramide from the Stem Bark of Odyendyea gabonensis, Zeitschrift für Naturforschung B, 68, 8, (2013), 924-930

https://doi.org/10.5560/znb.2013-3132

[16] Anjali Ganjare, Nishikant Raut, Nutritional and medicinal potential of Amaranthus spinosus, Journal of Pharmacognosy and Phytochemistry, 8, 3, (2019), 3149-3156

[17] María González-Rodríguez, Clara Ruiz-Fernández, Vera Francisco, Djedjiga Ait Eldjoudi, Yousof Ramadan Farrag AbdElHafez, Alfonso CorderoBarreal, Jesus Pino, Francisca Lago, Manuel Campos-Toimil, Glaucimeire Rocha Carvalho, Thiago Melo Costa Pereira, Oreste Gualillo, Pharmacological Extracts and Molecules from Virola Species: Traditional Uses, Phytochemistry, and Biological Activity, Molecules, 26, 4, (2021), 792 https://doi.org/10.3390/molecules26040792 